\title{
REPRESENTAÇÕES FEMINISTAS NA OBRA EXAGEROS E DELICADEZAS, DE CARLA NOBRE
}

\author{
FEMINIST REPRESENTATIONS IN THE BOOK EXAGEROS E DELICADEZAS, BY CARLA NOBRE
}

\section{RESUMO}

Fundamentado nos pressupostos do Feminismo, este trabalho tem como objetivo analisar as manifestações feministas na obra Exageros e delicadezas (2004), de Carla Nobre, onde será possível compreender as leituras feministas e de gênero como leituras políticas, vinculadas às relações de poder existentes na sociedade. Essa investigação dá destaque às formações de estereótipos que deram título ao livro de "delicada" e "exagerada" que se desmistificam ao longo do texto. É uma pesquisa bibliográfica, de análise literária e caráter imanente, tendo como principais bases teóricas as autoras Naomi Wolf (2018) e McCanner (2019). Dentre as criações literárias do estado do Amapá, a obra de Nobre é a primeira a representar a luta das mulheres de forma clara e objetiva, e a partir de suas poesias, o artigo mostrará a perspectiva feminista da literatura e sua importância para a formação social, de forma que as representações de gênero e também as convenções estéticas demonstrem valores, atitudes e crenças que estão enraizadas em uma sociedade.

Palavras-chave: Feminismo. Literatura amapaense. Relações de poder.

\begin{abstract}
Based on the assumptions of Feminism, this work aims to analyze the feminist manifestations in the work Exageros e delicadezas (2004), by Carla Nobre, where it will be possible to understand how feminist and gender readings as political readings, linked to the power relations existing in society. This investigation highlights the formations of stereotypes that gave the book the title "delicate" and "exaggerated" that are demystified throughout the text. It is a bibliographic research, of literary analysis and immanent character, having as main theoretical bases the authors Naomi Wolf (2018) and McCanner (2019). Among the literary creations of the state of Amapá, a work by Nobre is the first a representation of a women's struggle in a clear and objective way, and from his poetry, the article will show a feminist perspective of literature and its importance for a social formation, so that gender representations and also as aesthetic conventions demonstrate values, attitudes and beliefs that are rooted in a society.
\end{abstract}

Key-words: Feminism. Literature of Amapá. Power relations.

Jorlaíne Monteiro Girão de Almeida

Instituto Federal do Amapá (IFAP). E-mail: jorlaine.almeida@ifap.edu.br

Yurgel Pantoja Caldas

Universidade Federal do Amapá (UNIFAP). E-mail: yurgel@uol.com.br 


\section{Introdução}

O trabalho tem como objetivo geral analisar as manifestações feministas na obra Exageros e delicadezas (2004) de Carla Nobre, onde será possível compreender as leituras feministas e de gênero como leituras políticas, vinculadas às relações de poder existentes na sociedade. É uma pesquisa bibliográfica, de análise literária e caráter imanente, tendo como principais bases teóricas as autoras Naomi Wolf (2018) e McCanner (2019). Traz ainda como objetivos específicos: demonstrar a perspectiva feminista da literatura macapaense e sua importância para a formação social; e identificar a forma que as representações de gênero e também as convenções estéticas demonstram valores, atitudes e crenças que estão enraizadas em uma sociedade.

O livro Exageros e delicadezas (2013), da autora macapaense Carla Nobre reúne mais de 50 poemas que retratam a realidade da mulher e reformulam o estereótipo utilizado no título de "delicada" e "exagerada" formado socialmente ao longo do tempo, conforme constata-se em Marx apud Beauvoir (2009, p. 133): "Assim é que as qualidades inerentes à mulher são deturpadas em seu próprio detrimento, e todos os elementos morais e delicados de sua natureza se transformam em meios de escravizá-la e fazê-la sofrer".

Os poemas que serão analisados retratam a realidade feminina em várias esferas, como a vida profissional, a realidade delas com várias jornadas de trabalho, as dificuldades em criar os filhos sozinhas devido à condenação social, a recriminação da sua sexualidade, a criação do mito da beleza para coerção social, a recriminação no uso de palavras e comportamentos considerados vulgares, a luta delas por seu espaço profissional e por equiparação salarial e contra a violência sexual. (WOLF, 2008)

Dentre as criações literárias macapaenses, a obra de Nobre é a primeira a representar a luta das mulheres de forma clara e objetiva. Outras autoras como Maria Helena Amoras em sua obra Macapá: um rastro de pirilampos (1997) trazem alguns aspectos feministas, mas negam o feminismo de forma contundente devido à resistência existente em torno do termo.

\section{Carla Nobre}

Carla Nobre traz muita representatividade feminista em suas obras. Suas poesias apresentam a realidade da mulher da atualidade, com seus desafios e julgamentos. A autora é macapaense, professora de Literatura e Língua Portuguesa, mãe de dois filhos, coordenadora do grupo Abeporá da Palavras, nasceu no dia 1o de julho de 1975. Publicou as obras Ao Vento (crônicas e poemas, 2005) e Servindo Haicais (2005), em edições artesanais (computador); Sobre o Adeus e o Encelado de Saturno (poemas, Scortecci, 2007). 
Carla já ganhou as seguintes premiações nacionais: Menção Honrosa pelo poema "Anel de formatura", no concurso da Biblioteca Prof. Gerson Alfio de Marco, em Descalvado (SP). Menção Honrosa pelo poema “Escolha”, no 1ํㅡㄴ Concurso Nacional de poesia Audifax Amorim, em Colatina (ES). Menção Honrosa pelo poema "Um beijo longo" e pela crônica "Sou de significados", no 9º Concurso Literário Prêmio Missões, promovido pela Igaçaba Produções, em Roque Gonzáles (RS). $3^{\circ}$ lugar com o poema "O homem, os garis e uma casca de laranja", no ıo Concurso de Poesia Falada da Fundação Cultural Casimiro de Abreu, no município do mesmo nome, Estado do Rio de Janeiro. Menção honrosa pelo poema "Presente de férias", no 1o Concurso Apem de Literatura, em Marília (SP). Participação na Tribuna da OFFFLIP/2006 evento paralelo à Festa Literária de Paraty (RJ), para leitura dos poemas "Vento da

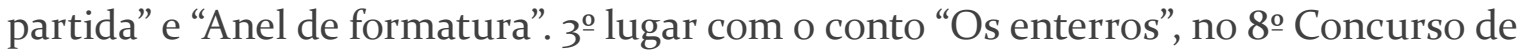
Literatura - 2006 da Fundação Cultural de Canoas (RS).

Nobre desenvolve um trabalho voltado para a difusão da literatura produzida na Amazônia. Organiza e participa de saraus literários, produtos de literatura, como agendas e livros artesanais. Seu trabalho envolve a poesia falada de seus autores favoritos. Acredita que recitar é divertido, saboroso e faz bem para a alma. A representatividade feminina em sua obra Exageros e delicadezas (2004), é o objeto desta análise.

\title{
"Soneto da palavra nua" e a escolha das palavras
}

O poema "Soneto da palavra nua" (NOBRE, 2013, p. 29) é o primeiro da obra a quebrar os paradigmas femininos. O poema se inicia com uma metalinguagem, citando sua criação, onde as delicadezas, características da formação literária feminina, são substituídas pelas "palavras nojentas" e por uma "linguagem piolhenta”. Na sequência o eu lírico destaca sua coragem em não se envergonhar de suas escolhas, visto que todas as palavras deveriam ser adequadas ao falar da mulher, palavras não deveriam ser seletivas, no contexto social e profissional. Por fim, o eu lírico escolher o verbo "parir" que representa a força da mulher no ato da reprodução e deixa implícito todos os condicionamentos referentes a tal, quando destaca a memória presente na palavra.

\author{
SONETO DA PALAVRA NUA \\ Quero para minha poesia \\ Todas as palavras nojentas \\ As obscuras, as ambíguas \\ Uma linguagem piolhenta \\ Não me envergonho das minhas escolhas \\ Minha palavra é minha pepita \\ Catarro, mentira, dor, sangue \\ Suvaco, urubus, bruxaria, bauxita
}


Todas as palavras são bem-vindas

E com elas as penas, a moela, as tripas

E todos os seus sentimentos e suas histórias

Das mais tristes às mais lindas

Fico com o verbo parir

E toda a sua memória (NOBRE, 2013, p. 29)

A literatura feminista atual vem apresentando um trabalho de crítica ao pensamento patriarcal, lutando para desconstruir as definições do antigo feminino. Os trabalhos literários femininos até o século XX ainda traziam os estereótipos femininos que normalmente ocorriam no ambiente doméstico, que são praticados através do fazer manual e com delicadeza (WOLF, 2018). A poesia de Nobre mostra justamente o contrário, o espaço da mulher na literatura sem essas marcações da feminilidade, com críticas ácidas e palavras agressivas.

O padrão delicado da mulher a descarta enquanto indivíduo, que segue modelos criados por homens para se sentir olhada e valorizada. No entanto, na realidade, existe uma busca incansável para o encaixe nesse padrão que está além da realidade, ou alcançado através de muitos sacrifícios. Portanto, a mulher deixa de valorizar suas características físicas e psicológicas para criar outras em virtude do agrado de outrem. (WOLF, 2018)

A diferença social está estereotipada também quando se propõe manifestações em que o corpo da mulher é mostrado nu. Existe estranhamento e violência por parte da sociedade quando isso ocorre. Enquanto os homens são ensinados a exibirem seu corpo, seja ele urinando na rua, ou mostrando o corpo para os familiares como forma de orgulho de seu desenvolvimento, as mulheres são doutrinas a cobrirem o corpo, fecharem as pernas, envergonharem-se de seu corpo e nem sequer tocar na palavra vagina. A repressão sexual continua atual para as mulheres, principalmente as que vêm de família religiosa que prega o puritanismo. (MCCANNER, 2019)

No título do poema a palavra "nua" (NOBRE, 2013, p. 29) retrata a utilização de termos não adequados à mulher. Mas apresenta também a coibição da nudez feminina. A culpa religiosa reprime sua sexualidade, no entanto, estimulam a compulsão masculina. A repressão foi tão significativa que vários mecanismos de controle (mutilação) sexual foram criados para que elas não pudessem sentir prazer e assim se desvencilhar de sua tarefa primordial da procriação e cuidados com os filhos e a casa. No Egito e em vários países da África, a clitoridectomia é um ritual de passagem realizado há mais de dois mil anos com o objetivo de impedir que a mulher tenha prazer sexual. O ritual pode acontecer na primeira semana de vida da mulher ou até a adolescência, onde pode ser retirada uma parte do clitóris e até os pequenos lábios da vagina. A dor é intensa devido à precariedade do procedimento, causando em muitos casos infecções e esterilidade e é utilizado até os dias atuais, mostrando que a luta pela liberdade sexual está longe de terminar. (MCCANNER, 2019) 


\title{
"Soneto íntimo" e a luta das mulheres
}

"Soneto íntimo" é, na sequência, o segundo poema de Nobre a retratar a luta da classe feminina. O eu lírico retrata as "loucuras" e o atrevimento das mulheres quando invadiram os quartéis, o que pode ser relacionado ao contexto da ditadura militar, onde as mulheres eram torturadas e mortas por seus envolvimentos em grupos políticos. Desafiaram o papel feminino tradicional, participando de movimentos estudantis, partidos e sindicatos. Ainda que em menor número que os homens, armaram-se e lutaram para derrubar o regime militar. Foram duramente reprimidas e ainda assim, elas que iniciaram o movimento pela anistia (MCCANNER, 2019). No trecho "a vida sempre foi nossa prioridade" temos a luta em defesa da vida, a contravenção delas pelo direito da luta e de liberdade:

\author{
SONETO ÍNTIMO \\ Pela vida já fomos e somos \\ Capazes de qualquer loucura \\ Pela vida somos atrevidas \\ Aliamos garra e ternura \\ Pela vida invadimos quartéis \\ Mudamos de identidade \\ Gritamos nas avenidas \\ A vida sempre foi nossa prioridade \\ Tratamos a vida como amálgama arrebatadora \\ Fogo, gelo, cristal e pérola \\ A vida nos faz cicatrizar e recomeçar \\ Ela é nossa matriz encantadora \\ E nos dá a mão: Vem comigo, Mulher, margarida \\ Somos pura contravenção! (NOBRE, 2013, p. 33)
}

As manifestações protagonizadas por mulheres continuam acontecendo nas ruas e pelas redes sociais. Em 2015 o projeto de lei 5069/2013, apresentado por Eduardo Cunha, dificultava os cuidados médicos por vítimas de estupro, o acesso à pílula do dia seguinte e ao aborto em casos de estupro. Rapidamente mulheres de todo o Brasil organizaram movimentos nas ruas e na internet através de hashtags. Essa luta alcançou patamares inéditos para a luta feminista. Outro movimento lançado nas redes sociais reivindicava a favor da amamentação em público, onde as mulheres são retaliadas ao mostrarem os seios, sendo orientadas desde sempre a esconder o corpo com um pano. $\mathrm{O}$ movimento atingiu grandes proporções e foi divulgado por mulheres de todo o Brasil. Hollanda (2018, p. 32) apresenta as marcas desse ativismo contemporâneo:

Há pelo menos dois pontos a serem destacados acerca dos modos de organização dos ativismos contemporâneos que eclodiram em junho de 2013 e são a marca do feminismo atual. Por um lado, a 
busca pela horizontalidade, a recusa da formação de lideranças e a priorização total do coletivo. Por outro lado, uma linguagem política que passa pela performance e pelo uso do corpo como a principal plataforma de expressão. Esses são os elementos que se notam à primeira vista nas novas manifestações feministas.

A luta pelos direitos da mulher em um contexto internacional tem recebido crescente hostilidade devido às manifestações de ódio, de intolerância e de rejeição aos direitos conquistados pelas mulheres, pelas comunidades indígenas, pelas populações negra, e pelas pessoas pertencentes aos grupos LGBTI, dentre outros grupos e comunidades que vinham ganhando espaço. Essa intolerância é reflexo de atuais governantes de extrema direita que compartilham dessa premissa e que dão voz aos que antes faziam uso da máscara social do politicamente correto. Um dos fatores dessa intolerância crescente se dá em virtude da crise econômica de vários países que trouxe os velhos e preconceituosos julgamentos do crescimento econômico vinculado a homens brancos e ricos, daí a crescente discriminação. (HOLLANDA, 2018)

Mesmo diante do cenário discriminatório, a escolarização das mulheres vem crescendo em todos os níveis de ensino. Nos anos 2000, elas quebraram os paradigmas socias passando a ser maioria dos matriculados e concluintes do Ensino Fundamental, Médio e Superior. Com o crescimento do nível de escolaridade houve também um aumento significativo no número delas no mercado. Outro marco importante é o acesso das mulheres a profissões antes consideradas masculinas, como cargos de chefia e gerência. No entanto, as áreas tradicionalmente direcionadas à mulher ainda são a realidade da maioria. (MCCANNER, 2019)

\section{"Soneto da fábula da mulher" e a figura de feminilidade construída e desconstruída}

"Soneto da fábula da mulher" é outro poema de Nobre que indica algumas das formas pelas quais as identidades são construídas. O estereótipo feminino que a designa como: "princesa”, “delicada”, “cabelos longos” é substituído pela figura realista da "mulher normal", "cheia de sal”, "feita de Marabaixo", sugerindo que os tempos estão mudando, tornando aceitável que a posição feminina possa incluir a satisfação de desejos pessoais, bem como a cultura regional, representada aqui pelo Marabaixo nos permite trabalhar conceitos e temas provenientes de diferentes tradições culturais e supõe envolvimento direto e compromisso com diferentes grupos culturais, favorecendo a relação teórico-prática no que diz respeito à diversidade cultural. (VIDEIRA, 2009) 


\author{
SONETO DA FÁBULA DA MULHER \\ Era uma vez uma mulher \\ Que não nasceu da costela de ninguém \\ Ela era linda e comandava até as marés \\ Não ficou adormecida esperando o príncipe chegar \\ Não tinha medo do escuro, nem do lobo \\ E estava disposta a encarar \\ Era uma vez uma mulher de cabelos curtos \\ Que não gostava definitivamente de sapatinhos de cristal \\ Era uma vez uma mulher normal \\ Que brilhava na noite e respingava fogo \\ Ela era uma mulher cheia de sal \\ Era uma vez uma mulher feita de marabaixo \\ Gostava de gengibirra, muita folia e suor \\ E que ninguém queira apagar o seu belo e doce facho! \\ (NOBRE, 2013, p. 36)
}

O verso "Que não nasceu da costela de ninguém" (NOBRE, 2013, p. 36) apresenta a história da criação segundo a tradição judaico-cristã que estabelece a concepção da mulher a partir do homem, tornando-a um ser de segunda classe: "Mandou, pois, o Senhor Deus um profundo sono a Adão; e, enquanto ele estava dormindo, tirou uma de suas costelas [...]" (BÍBLIA, Gênesis 2, 21-23). Então, segundo a Bíblia, Deus criou o homem a sua imagem, enquanto a mulher é criada a partir de uma costela descartável, deixando clara a superioridade do homem à mulher, segundo o texto bíblico.

A criação da mulher a partir de uma outra criatura perfeita traz a ela uma necessidade de aperfeiçoamento constante. Elas sempre acham que necessitam de acabamento. Seu corpo é cheio de impurezas e imperfeições (tanto por conta do fator criação, quanto pelo pecado original). Segundo Wolf (2018, p. 141), essa visão fez a mulher seguir os Ritos da Beleza que se propõem a queimar o corpo feminino no forno da beleza, e a eliminar suas impurezas, a lhe dar acabamento.

No verso "Ela era linda e comandava até as marés" (NOBRE, 2013, p.36) observase que o apego à beleza acontece mesmo após a superação da Mística Feminina da domesticidade, onde o mito da beleza foi redirecionado amarrando as mulheres na indústria da beleza compulsória, ainda que sejam espetacularmente independentes e profissionais, como fica claro no comando das marés do eu lírico, a beleza é um fator de controle social da mulher. (WOLF, 2018).

Os versos "Não ficou adormecida esperando o príncipe chegar/ Não tinha medo do escuro, nem do lobo" (NOBRE, 2013, p. 36) trazem a libertação do padrão "princesa" ensinado às meninas quando crianças. Essas meninas são instruídas a falar baixo, sentar-se adequadamente, andar de salto e com lindos vestidos, e o pior de tudo é a submissão que é vinculada à figura do príncipe que aparece para salvá-la de seu cruel destino. O eu lírico liberta a si e a outras com suas palavras, ressaltando 
a importância da independência feminina para que elas tenham voz e não fiquem presas a relacionamentos abusivos por dependência financeira. (MCCANNER, 2019).

A libertação apresentada pelo eu lírico também é evidente nos versos "Era uma vez uma mulher de cabelos curtos/ Que não gostava definitivamente de sapatinhos de cristal" (NOBRE, 2013, p. 36). Aqui também é desconstruída a beleza da mulher que normalmente é vinculada aos cabelos longos e sapatos brilhantes. Os versos "Era uma vez uma mulher normal/ Gostava de gengibirra, muita folia e suor/ E que ninguém queira apagar o seu belo e doce facho!” (NOBRE, 2013, p. 36) também reforçam essa quebra de padrão, trazendo uma mulher que se diverte, que sua, e que tem seus desejos sexuais libertos.

\section{"Soneto da minha rebelião": um retrato da violência sexual}

No poema "Soneto da minha rebelião" observa-se a descrição do período político e de suas campanhas. Tem-se a retratação das falsas promessas de campanha e a crítica em relação às "farras" que são feitas por eles na pré e pós-campanha. Além da crítica política, nota-se no segundo verso a retratação do estupro, que neste caso pode ser relacionado ao rombo nos cofres públicos em virtude da corrupção que assola o Brasil, mas que também podemos relacionar aos altos índices de estupros ocorridos no país, no qual os governantes não se atentam ao alarmante aumento ano a ano desses apontadores, não priorizando o combate a esse crime nas políticas de segurança nacional:

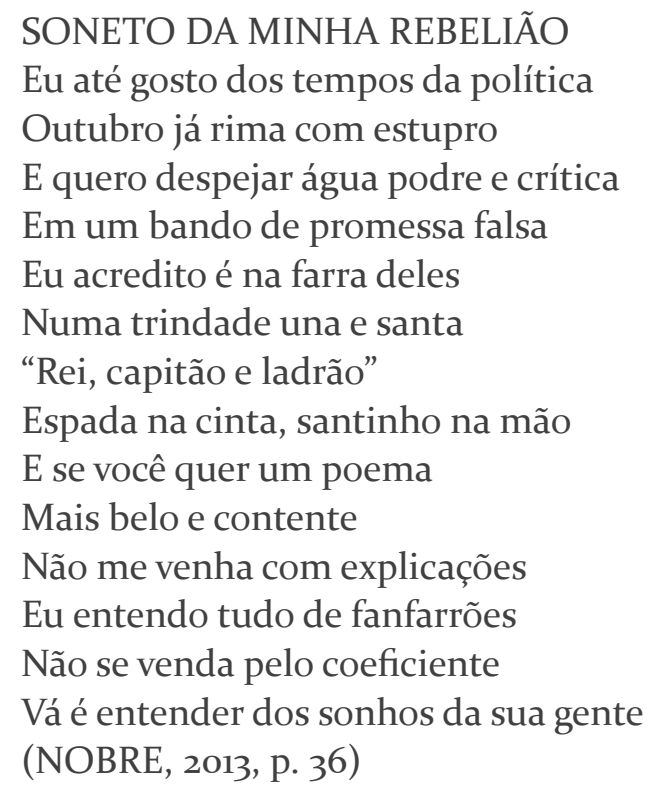

O jornal Agência Brasil divulgou a pesquisa realizada pelo 13 $3^{\underline{a}}$ Anuário Brasileiro de Segurança Pública (2019) que registrou recorde da violência sexual. Foram 66 mil vítimas de estupro no Brasil em 2018, maior índice desde que o estudo 
começou a ser feito em 2007. A maioria das vítimas (53,8\%) foram meninas de até 13 anos. Conforme a estatística, apurada em microdados das secretarias de Segurança Pública de todos os estados e do Distrito Federal, quatro meninas até essa idade são estupradas por hora no país. Ocorrem em média 180 estupros por dia no Brasil, 4,1\% acima do verificado em 2017 pelo anuário.

Quando se discute estupro tende-se a culpabilizar com frequência a vítima, defendendo a lógica da biologia de que os homens são movidos por instinto em busca de sexo, e que a vítima facilitou de alguma forma a ação do estuprador. Essa facilitação aconteceria pela forma que a mulher estava vestida, pelo seu estado de embriaguez ou por estar sozinha durante à noite. De toda forma, o crime sempre era responsabilidade da mulher, que muitas vezes, por vergonha, deixou de denunciar o agressor. O desejo sexual masculino nunca foi reprimido. (RIBEIRO, 2018).

A partir dos anos de1970 as feministas passaram a desafiar a reação da sociedade ao estupro e a introduzir a violência sexual motivada pelo poder. Brownmiller apud McCanner (2019, p. 168) divulgou em sua pesquisa que desde a pré-história o homem reafirma o domínio sobre a mulher através do estupro. E que o ato é consciente, não passional, no qual reivindica seu poder sobre o corpo das mulheres. A autora defende também que o sentimento de posse é dado ao homem pela discriminação social que coloca a mulher em condição de inferioridade e reforça o papel dominador do homem que a vê como propriedade. O pior disso tudo é que o grupo de estupradores não se limita aos maníacos, mas sim homens considerados honrados, que além de mulheres adultas, estupram as crianças de seu próprio lar.

O estupro marital não existia na lei até o século XX. Um retrato dessa visão dominadora do homem aconteceu no século XVII quando o juiz inglês Sir Mattew Hale determinou que o estupro conjugal não poderia existir judicialmente. Ele defendia que o casamento dava plenos poderes ao homem ao corpo da mulher e que ela ao se casar consentia o sexo pelo resto da vida com o marido. O estupro matrimonial só se tornou crime no século XX quando foi estabelecido pela ONU como uma violação de direitos humanos em 1993. No entanto apenas 52 dos 193 países integrantes da ONU o consideram crime, e grande parte desses países que não acataram essa visão baseiam-se em discursos religiosos que são conduzidos por homens, fazendo com que o direito da mulher seja extirpado. (MCCANNER, 2019).

A partir de 2010, com a amplitude da quarta onda feminista, as manifestações públicas aumentaram em todo o mundo lutando contra a visão condenatória social da vítima de estupro. Um dos movimentos mais importantes ocorreu em 2011, em Toronto, Canadá, com a Marcha das Vadias. O termo faz referência à mulher que quando violentada era condenada por estar utilizando trajes de "vadia" fazendo com que o "instinto sexual" masculino agisse. O movimento já chegou à sétima edição e luta cada vez com mais veemência conta essa visão, deixando clara a autonomia da mulher sob seu próprio corpo. (MCCANNER, 2019).

No Brasil, atualmente, a militância feminista jovem luta pela causa através das redes sociais. Djamila Ribeiro é uma dessas ativistas que lutam pela causa através de suas publicações em livros e pelas redes. A violência sexual, o assédio no transporte 
público, as agressões psicológicas tem ganhado visibilidade na sociedade através da hashtags de denúncias e mobilizações. Esses movimentos que se iniciam nas redes perpassam para manifestações de ruas e ações judiciais, incentivando as mulheres a lutarem pela liberdade e pelo respeito. (RIBEIRO, 2018)

\title{
"Minha linhagem" e a segregação profissional das mulheres
}

No poema "minha linhagem" (NOBRE, 2013, p. 52) o eu lírico inicia a obra com a descrição de sua intromissão em lugares em que não é chamada, nesse tópico podemos analisar os vários setores em que a mulher foi excluída e que ao longo do tempo vem buscando o seu lugar. No âmbito profissional muitos setores ainda segregam as mulheres, que preferenciam homens para a ocupação dos cargos, devido a tripla jornada delas de atividades domésticas e familiares. E mesmo conquistando os cargos elevados, elas ainda recebem menos que os homens, e os índices só pioram quando falamos de mulheres negras (MCCANNER, 2019). No último verso observase mais uma vez a quebra dos padrões de feminilidade quando o eu lírico se auto descreve como mulher "mal comportada":

\author{
MINHA LINHAGEM \\ Sou daquelas \\ Que mete o nariz \\ Onde não é chamada \\ Sou mulher para ser amada \\ Sou daquelas para quem \\ É tudo ou nada \\ Não aguento gente \\ Que é só fachada \\ Abrigo os sonhos \\ Em enseadas felizes \\ Faço revoadas \\ Com minhas cicatrizes \\ Sou de uma linhagem \\ Que não nega a jornada \\ E toda a minha linguagem \\ É de mulher mal comportada \\ (NOBRE, 2013, p. 52)
}

Um estudo feito pelo Instituto Brasileiro de Geografia e Estatística (IBGE) e divulgado pelo jornal Agência Brasil em 2019 mostra que as mulheres ganham menos do que os homens em todas as ocupações selecionadas na pesquisa. Mesmo com uma queda na desigualdade salarial entre 2012 e 2018, as trabalhadoras ganham, em média, 20,5\% menos que os homens no país. O que ratifica a importância da temática utilizada por Carla Nobre pela luta por seu espaço e por igualdade social. 
Além da diferença salarial, as mulheres também estão vulneráveis ao julgamento masculino no ambiente de trabalho. Um dos grandes problemas relacionado ao mercado é o chefe que qualifica o trabalho de acordo com a idade, beleza e ausência de filhos. O número de casos de assédio sexual no trabalho é alarmante. As mulheres precisaram ter muito jogo de cintura para se manterem nos empregos por conta de chefes assediadores, onde o "não" da mulher significava sua demissão. Elas apresentam tensão dentro e fora do ambiente de trabalho em virtude da forma que se vestem, onde muitas ainda se sentem culpadas por acreditar que incitam o assédio. (MCCANNER, 2019).

O julgamento social voltado para a beleza e à forma que elas se vestem ainda é muito presente na contemporaneidade. Os homens continuam a disseminar o poder feminino de sedução e o quanto as mulheres o utilizam para conseguir cargos e vantagens no trabalho (WOLF, 2018). Enquanto uma pesquisa de 2017 do Datafolha divulgada no jornal virtual A tarde demonstra que os casos de assédio sexual no Brasil ainda são uma preocupação para as mulheres, onde $42 \%$ das brasileiras afirmaram já terem sofrido assédio no ambiente de trabalho.

\section{O mito da beleza e a repressão sexual nos poemas "Fêmea" e "Cansei de ser sereia"}

O poema "fêmea" (NOBRE, 2013, p. 54) traz a visão social da mulher que teve vários casamentos quando se utiliza do termo "mulher usada", descrevendo a discriminação da sociedade que ainda remete aos séculos passados, em que a mulher divorciada era subjugada como má esposa e/ou má mãe. No entanto, a realidade é outra, grande parte das mulheres do século passado assumiam o papel de mulher perfeita e aceitavam todas as condições de tratamento, infidelidade e ausência física ou moral de seus maridos. Essa imposição social dava a elas a obrigação de cuidar da casa, dos filhos, do marido e estar sempre disponíveis, amáveis e felizes com a chegada de seus parceiros. Isso acontecia, principalmente, pela dependência financeira de seus maridos que ao tirá-las da casa dos pais assumiam a responsabilidade total sobre elas (WOLF, 2018). Com a universalização do movimento feminista as mulheres expuseram as suas insatisfações e lutaram pela liberdade financeira que as mantinha presas ao casamento, com isso o número de divórcios vem aumentando e a maioria dos pedidos de separação são solicitados por elas.

\section{FÊMEA}

Sou uma mulher usada

Passada de mão em mão

Tive 3 filhos 5 maridos intensas paixões

Trago em mim todos os nomes

Os medos as aflições as dores as maldições

E esse olhar forte de fêmea 
Sou fêmea das ladeiras e periferias

Não uso unha de pelúcia

Não aguento fricote

Meu macho tem que ser alguém

Que ame coma dê lambida faça comidinha

E que não me boicote

Sou fêmea assumida

Nasci na floresta

Como farinha maniçoba e taperebá

(NOBRE, 2013, p. 54)

Os versos "Os medos as aflições as dores as maldições/ E esse olhar forte de fêmea" (NOBRE, 2013, p. 54) remetem ao padrão de debilidade e delicadeza constituído ao longo do tempo para contenção das mulheres, o exemplo de perfeição vem sendo substituído pela realidade corporal da mulher e a aceitação de sua força fora do padrão. $\mathrm{O}$ modelo social de beleza feminina muda muito ao longo do tempo. O padrão que era imposto na Grécia antiga (500 a.C. a 300 a.C.) é muito diferente do atual. Antes o belo se dava através de formas corpulentas, hoje essas formas são quase consideradas anomalias. Na atualidade, dependendo do lugar, as formas variam entre o corpo escultural ou o extremamente magro. No entanto, o padrão de beleza atual tem caudado transtornos à vida da mulher, que ao tentarem se encaixar acabam recorrendo à uma alimentação não saudável, através das dietas, ou à cirurgia plástica, e a várias outras formas prejudiciais à saúde. (WOLF, 2018).

Os jovens e adolescentes são vítimas desse mal, pois buscando aceitação da sociedade acabam recorrendo a remédios para emagrecer, anabolizantes para crescimento muscular, procedimentos químicos no cabelo e no corpo em busca do corpo "ideal". A cada ano é constante o aumento do número de jovens que adquirem Bulimia e Anorexia, o que comprova os transtornos causados pela imposição social. (WOLF, 2018).

Essa visão é colocada em xeque no poema de Nobre que questiona o padrão social imposto da mulher "barbie", o mito da beleza que estabelece um modelo a ser seguido por mulheres perfeitas, aquela que precisa estar sempre maquiada, de salto, com roupas justas e com o corpo magro:

Ser barbie tá fora de moda

E dentro de mim inteira

Um coração pulsa ligeiro

Minha vagina estala

E quando eu não quero nada

Vou dormir feliz também

Sou fêmea para dizer não

Sou fêmea para deitar de costas

Seja de sono ou de tesão

Trago em mim a TPM

E rezo pra tudo quanto é santo 
Visto saia jeans fico nua

Sou fêmea para derrubar

Qualquer muro ou compromisso

E ainda que eu leve um tiro

Levo também comigo

A alegria de ter tentado

Meu coração sempre vai em paz e bem cuidado

(NOBRE, 2013, p. 55)

De acordo com Wolf (2018, p. 31): "o mito da beleza não tem absolutamente nada a ver com as mulheres, ele gira em torno das instituições masculinas e do poder institucional dos homens", diante de tal afirmação a conclusão que se tem é de que as mulheres continuam seguindo os padrões estabelecidos pela sociedade patriarcal e tentam ao máximo encaixar-se nele, mesmo diante da evolução do movimento feminista. Esse padrão inalcançável estabelecido por eles acaba trazendo vários transtornos à vida da mulher que acaba recorrendo a cirurgias plásticas e a dietas doentias. O Brasil está em segundo lugar no ranking dos países que mais são adeptos da cirurgia plástica no mundo, perdendo apenas para os Estados Unidos. Os números de cirurgias crescem a cada ano, mesmo diante de crises econômicas atuais. Naomi Wolf (2018, p. 26) ratifica essa condição quando diz que seguimos numa condição pior que as das mulheres das décadas anteriores, quando se fala em padrão de beleza:

Mesmo assim, em termos de como nos sentimos do ponto de vista físico, podemos realmente estar em pior posição do que nossas avós não liberadas. Pesquisas recentes revelam com consistência que, no mundo ocidental, entre a maioria das mulheres que trabalham, têm sucesso, são atraentes e equilibradas, existe uma "subvida" secreta que envenena nossa liberdade: impregnada de conceitos de beleza, ela é um escuro filão de ódio a nós mesmas, obsessões com o físico, pânico de envelhecer e pavor de perder o controle.

Outro ponto muito relevante do poema diz respeito ao consentimento à relação sexual. No trecho "Sou fêmea para dizer não" (Nobre, 2013, p. 55), o eu lírico apresenta um dos grandes problemas nas relações afetivas: o respeito à mulher e à sua vontade. Grande parte dos homens veem as mulheres como posse, e têm como premissa a satisfação sexual dele como obrigação dela mesmo que contra a sua vontade, o que caracteriza o estupro. No trecho "Visto saia jeans fico nua" (Idem) observa-se a liberdade de escolha da vestimenta feminina, o que ainda é motivo de retaliação da sociedade atual. O estupro ainda é associado à vestimenta e ao comportamento da mulher, mesmo numa sociedade com acesso à tanta informação.

No poema "cansei de ser sereia" (Nobre, 2013, p. 56-59) o eu lírico reforça a fuga ao padrão social do corpo esbelto com intervenções cirúrgicas. Os versos "Meu peito é mole, sim” e "Minha bunda é caída” (Idem) reforçam a busca pela aceitação 
social além dos padrões de beleza, onde a mulher se orgulhe do que é e do que faz e se desvincule dessa imposição para o seu próprio bem.

No verso "Minha vontade/ Bole no mundo" (idem) destaca-se a liberdade sexual conquistada pela mulher que durante séculos foi alvo de severa repressão, por conta, principalmente, da religiosidade que ligava o sexo ao pecado. Por esse motivo, a sexualidade da mulher era realizada apenas para fins de procriação. O mesmo não se aplicava aos homens, que satisfaziam seus desejos com outras mulheres, o que não era condenado socialmente (MCCANNER, 2019). Os versos "Plena de desejo/ Não tenho medo de olhar,/ De arranhar, de gritar...” (idem) demonstram a condição dela na atualidade, em que a mulher vem conquistando sua liberdade em todos os âmbitos. Sua sexualidade, embora ainda muito reprimida, ganhou uma visão mais positiva, onde já é possível falar em satisfação sexual sem a condenação pecaminosa:

CANSEI DE SER SEREIA

Meu peito é mole, sim

Minha boca é carnuda

E eu gosto

Meu jogo é aberto

E eu posso

Minha vontade

Bole no mundo

Não sou de esconder as estrias

Não tenho medo da celulite

Eu sou Fada

Dama da noite

Afrodite

Não me venha com papo furado

De tia ou madrinha

Minha bunda é caída,

Sim, senhor!

E não é por isso que eu vou

Tapar o sol com a peneira

O que eu não tolero

É asneira

Eu sou uma mulher inteira

Plena de desejo

Não tenho medo de olhar,

De arranhar, de gritar...

Só não me venha

com modelos

Que eu não sou de apelar

Eu ando no mundo

Com o salto

que eu quiser

Eu me jogo do trampolim

me atiro sem para quedas

fumo 


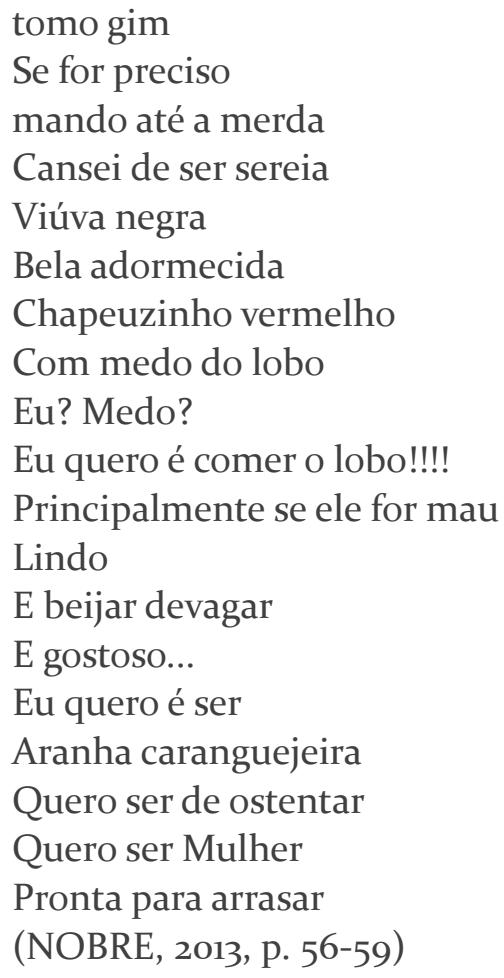

Os versos "Só não me venha/ com modelos" (NOBRE, 2013, p. 56-59) reforçam o padrão estético da atualidade, em que as mulheres fazem loucuras para emagrecer e alcançar a "beleza" das modelos magérrimas das capas de revistas. Wolf (2018, p. 28) afirma que "o peso das modelos despencou para $23 \%$ abaixo do peso das mulheres normais, a incidência de transtornos alimentares aumentou exponencialmente e foi promovida uma neurose em massa", essa neurose é uma das formas de controle da mulher, o que antes era feito através do casamento, controle de natalidade e situação financeira.

Nos versos "Cansei de ser sereia/ Viúva negra/ Bela adormecida/ Chapeuzinho vermelho/ Com medo do lobo" (NOBRE, 2013, p. 56-59) atenta-se ao padrão feminino criado pelos contos de fadas. Wolf (2018, p. 94) afirma que "A cultura estereotipa as mulheres para que se adequem ao mito, nivelando o que é feminino em beleza-sem inteligência ou inteligência sem beleza”, ou seja as mulheres devem escolher entre uma mente ou um corpo desenvolvido, os dois não. Segundo a cultura masculina, uma mulher que demonstre personalidade não é desejável, pois o padrão impõe mulheres ingênuas. A mulher passa a ser um objeto artísticos para contemplação. Estés (2018, p. 212) ratifica a visão de Wolf quando afirma que nos esforçamos demais para conter os impulsos e contrações da criatura selvagem e adequarmos ao padrão de damas educadas, recatadas contidas e reprimidas. 


\section{A carga de trabalho das mulheres e a manutenção do status da beleza na obra "Para minhas filhas"}

No poema "para minhas filhas" temos o reflexo da realidade feminina, as atividades domésticas como serviço vinculado à sua realidade social, pois mesmo que a mulher, na atualidade, trabalhe fora, essas atividades são de sua exclusividade, ou pelo menos a maioria do trabalho. Nos versos "não quero para as minhas filhas/ a herança que herdei/ casa, comida, mobília” (NOBRE, 2013, p. 62-63) observa-se essa realidade das mulheres sobrecarregas com excesso de trabalho, a realidade profissional delas mudaram, a doméstica não. Wolf (2018, p. 44) ratifica essa visão ao dizer que "embora uma mulher tenha o emprego remunerado em horário integral, ela ainda faz todo ou quase todo o trabalho não remunerado que antes fazia". Desse modo, a mulher tem mais tarefas, menos lazer e menos credibilidade profissional:

\section{PARA MINHAS FILHAS}

Não quero para minhas filhas

a herança que herdei:

casa, comida, mobília

cabelos em rabo de cavalo

e histerias

Quero que minhas filhas

Tenham o direito de serem livres

Tenham o direito de serem felizes

E se for preciso eu chamo todas as forças

Chamo a caridade da minha sogra Maria

A fome vencida pela minha vó Adelaide

Eu chamo a força das minhas ancestrais

Iemanjá, Maria de Nazaré, Zilda

E tudo o que arde dentro do nosso peito

Chamo os tambores das mães e seus terreiros

A força das flores em nossos canteiros

Para os sonhos das minhas filhas

Essa beleza que se inicia

Eu não abro mão da rebeldia

E defendo:

Não dá para ficar calada

Não dá para fingir que não viu

E não é porque tenho pavio curto

Não é porque eu sou mal amada

Meninas, somos todas humanas!

Olhos, nariz

Boca e gana

Quero que minhas filhas

Tenham o melhor dom:

Somos todas porta-vozes

Sem medo 
Sem receio

Quero que minhas filhas

Não fiquem no maldito meio termo

Usem todos os seus sentidos

E sejam rainhas dos seus desejos.

(NOBRE, 2013, p. 62-63)

As donas de casa de décadas passadas viviam isoladas, inseguras e entediadas e passavam boa parte do seu tempo buscando produtos domésticos e cosméticos que mantivessem sua visão de mulher/mãe organizada e produzida para a chegada do marido após a jornada de trabalho. Com a saída dessa mulher para o mercado, a indústria da beleza e os anunciantes precisaram de uma nova forma para manter os interesses da mulher no consumo de seus produtos. Wolf (2018) afirma que foi a partir de então que criou-se a visão da mulher "heroína" aquela que tem filhos, trabalha fora, cuida dos afazeres domésticos e está sempre linda, ela nunca envelhece, tem sempre uma fórmula para aquelas que "gostam" de cuidar de si. Junto a isso houve a caricaturização das mulheres de sucesso. Essas mulheres, bem como as líderes do movimento feminista eram vistas como feias, mal-amadas, mães relapsas, e as revistas para mulheres começaram a propagar a visão da "mulher perfeita" que é seguida até os dias atuais.

Mas por que as mulheres se importam com o que dizem as revistas femininas? Para Wolf (2018), essas revistas representam a cultura de massa, as mulheres encontram incentivo ao seu desenvolvimento tanto educacional quanto estético, esse tipo de incentivo não é normalmente encontrado pela sociedade em geral que condena grande parte dos atos das mulheres, mesmo que elas ajam conforme o figurino. Para desenvolver a confiança nas leitoras, essas revistas passaram a oferecer muito mais do que a seção destinada à beleza, a revista passou a fornecer "serviços reais , informa números telefônicos para a ajuda de emergência, apresentam pesquisas entre as leitoras, dão às mulheres ferramentas para preparar orçamentos e informações financeiras" (WOLF, 2018, p. 114).

O status da beleza isola as mulheres que são treinadas desde a infância para serem rivais. As mulheres aproximam-se pelo laço afetivo, mas não deixam de criticar umas às outras por sua aparência e beleza. Enquanto os homens são ligados sem hostilidade, em sua maioria, por seus pensamentos comuns como as páginas de futebol estampadas nas capas de jornais, interesses financeiros, dentre outros, as mulheres disputam entre si julgando e discriminando a outra pela maquiagem, tônus muscular, os sapatos, por acreditarem estar sempre em disputa uma com as outras. (WOLF, 2018)

Da revista, a visão da mulher sempre bela passou a ocupar o espaço da televisão e da internet. Além dos programas tradicionais de TV que normalmente tem uma mulher lindíssima como apresentadora e outras igualmente belas como repórteres, temos na atualidade os reality shows que tem como elenco, em sua grande maioria, mulheres malhadas, maquiadas, cheias de intervenções cirúrgicas no corpo que vem 
se tornando o sonho da massa feminina. A beleza padrão também é realidade nas exibições cinematográficas, as atrizes refletem um padrão quase que inalcançável para a maioria as mulheres, e o pior é que quando essas atrizes envelhecem se tornam alvo de críticas ferozes, não existe empatia em matéria de beleza. (WOLF, 2018)

A indústria pornográfica vem contribuindo com o novo modelo padrão de beleza das mulheres com tônus muscular perfeito e cheios de cirurgias plásticas. $O$ faturamento da indústria pornográfica é superior ao da cinematográfica tradicional (WOLF, 2018). Além disso, a submissão e a agressão visando a satisfação sexual apenas dos homens compões a maioria dos vídeos, o que deixa claro o padrão de mulher que os homens desejam manter com toda a sua força, o que contesta o verso de Carla Nobre ao dizer que gostaria que suas filhas "sejam rainhas dos seus desejos" (NOBRE, 2013, p. 62-63).

\title{
"Elegia para a tua beleza” e a condenação da mãe solo
}

Finalizando a análise da obra de Carla, seguimos com o poema "Elegia para a tua beleza” (NOBRE, 2013, p. 83) que foi uma homenagem para Joana D’arc dos Santos Alfaia. O eu lírico se despede de Joana que partiu inesperadamente e exalta a garra e a força dessa mulher que se formou e criou três filhos com toda a determinação. Um dos pontos mais importantes dessa obra é justamente o verso que cita a criação dos filhos: "Pariu três filhos e deu o seu jeito" (idem), num país em que de acordo com dados do Instituto Brasileiro de Geografia e Estatística (IBGE) divulgado no site do jornal Estadão (2017), 57,3 milhões de lares são chefiados por mulheres, isto é, $38,7 \%$ das casas. Apesar de ser uma situação comum, ser uma mãe solo é um grande desafio. Ainda 5,5 milhões não têm o nome do pai no registro de nascimento:

\author{
ELEGIA PARA TUA BELEZA \\ Não há certezas na vida \\ Também não há final na morte \\ Uma despedida é sempre uma oportunidade \\ De vencer os medos e a vaidade \\ Sua partida inesperada \\ Ainda arranca gotas de lágrimas \\ De sangue, de saudade, de perdão \\ Gotas do abraço perdido na tarde de sábado e solidão \\ É impossível preparar bem uma partida \\ Você bem que tentou com seu planejamento: \\ Deixou sorriso, costelinha de porco \\ Altar com flores, sapato alto e batom \\ Não adiantou! \\ Mas você também deixou no seu caminho \\ As gotas de sua delicadeza, o seu brilho \\ As gotas de sua coragem, a sua intensidade
}


O exagero no tom certo que você criou...

Gotas de sangue para olhar a vida

Com toda a liberdade e em seus vários lados

Sem nenhuma pretensão de escolher o melhor

Apenas seguindo o que manda o coração

Você deixou com a gente

Gotas de bondade e alegria

As gotas da beleza que desafia

A morte, a maldade, o desamor...

Você foi e deixou sua audácia

Foi no Japão e tocou o solo sagrado

Pariu três filhos e deu o seu jeito

Se formou, defendeu e dançou feliz

Você foi onde a morte não apaga a força feminina

Então leva contigo Joana, mulher e menina,

As gotas da nossa eterna lembrança e cura

Qualquer ferida com as gotas delicadas da esperança

(NOBRE, 2013, p. 83)

A crítica social em relação à mãe que cria seu filho sozinha é severa. Por isso, muitos movimentos vêm tentando mudar a nomenclatura de "mãe solteira" para "mãe solo" com o objetivo de mudar a forma como são vistas pela sociedade. As mulheres reivindicam por respeito, mostrando a cada dia seu profissionalismo, seu cuidado com os filhos, sua capacidade na criação dos filhos e manutenção dos lares sozinhas. Apesar de elas suprirem todas as necessidades de sua casa, se desdobrando em várias jornadas, o sentimento de culpa é uma realidade, pois não acham que fazem suficiente, ou que falta tempo para várias das tarefas e comportamentos sociais "padrões" que são disseminados por julgamentos alheios. Elas ainda se cobram pela falta de atenção, carinho e acompanhamento do pai, que em muitos casos após o nascimento ou separação, deixam os filhos de lado e correm atrás de seus objetivos pessoais, direcionando toda a responsabilidade para a mãe. Essa cobrança e esse esforço para suprir todas as necessidades físicas e psicológicas dos filhos deixam a maioria das mães em estado de exaustão, mas que não pode ser externado sob pena de julgamento e condenação social por se achar no direito de individualidade após a maternidade.

O verso "Você foi onde a morte não apaga a força feminina" (NOBRE, 2013, p. 83) representa a luta dessas mulheres por seus espaços. Quantas morreram por dignidade e igualdade? Quantas são vitimadas todos os dias enquanto apenas buscam liberdade de ir, vir e permanecer? Quantas são mortas por seus maridos e ex-maridos por terminarem o relacionamento? A luta cotidiana é árdua e se faz cada vez mais necessária. Vivemos em tempos de retrocesso, onde os direitos fundamentais estão sendo colocados à prova após anos de tanto labor. $\mathrm{O}$ incentivo à rivalidade precisa ser abolido e as mulheres precisam acreditar que, na realidade, elas são a segurança uma das outras, o que já ocorre em alguma escala quando há risco iminente de violência 
sexual, ou seja, quando ameaçadas por algum estranho se aproximando de forma suspeitas, elas sempre buscam outra mulher para se sentirem seguras. É necessário que entendam definitivamente que aqui não estamos em competição para a beleza ou para a perfeição, mas sim que cada uma busca seu espaço na sociedade com suas individualidades que devem ser valorizadas.

E individualmente o que devemos buscar? O que tivermos vontade. Vamos cativar a tolerância e a admiração pela escolha das outras mulheres, como fez o eu lírico na homenagem a sua amiga. Vamos escolher nossas próprias causas, sem a influência da necessidade em agradar os homens que já são tão favorecidos. Vamos enaltecer o trabalho das mulheres através de pesquisas que exaltem o seu trabalho. Busquemos a igualdade e apreciemos em outras mulheres as conquistas que são de todas nós.

\section{Considerações finais}

O estudo das manifestações feministas na obra Exageros e delicadezas (2004) de Carla Nobre possibilitou a compreensão das lutas feministas e de gênero como leituras políticas, vinculadas às relações de poder existentes na sociedade. Essa investigação deu destaque às formações de estereótipos que deram título ao livro de "delicada" e "exagerada" e que se destacam ao longo do texto.

Os poemas analisados retrataram a realidade feminina em várias esferas, como a vida profissional: a realidade delas com várias jornadas de trabalho; a luta delas por seu espaço profissional e por equiparação salarial e contra o assédio sexual; e a pessoal: as dificuldades em criar os filhos sozinhas devido à condenação social; a recriminação da sua sexualidade; a criação do mito da beleza para coerção social; e a recriminação no uso de palavras e comportamentos considerados vulgares.

Em linhas gerais, as poesias analisadas de Nobre apresentam uma linha precursora na representação da luta das mulheres de forma clara e objetiva, com poucos resquícios do patriarcalismo e do romantismo. Logo, a luta por causas igualitárias em tempos de crise humanitária se faz mais que necessária. Desse modo, pretende-se com esse estudo o acesso e a visibilidade que essas temáticas de autoras como a Carla Nobre exploram.

\section{Referências bibliográficas}

BARRETTO, Yasmim. Assédio sexual no trabalho vitima cerca de $\mathbf{4 2} \%$ das mulheres. Jornal A Tarde, or de nov. de 2018. Disponível em: https://atarde.uol.com. $\mathrm{br} / \mathrm{brasil} /$ noticias/2008848-assedio-sexual-no-trabalho-vitima-cerca-de-42-dasmulheres. Acesso em 13 de jan de 2020. 
BEAUVOIR, Simone de. O segundo sexo. Rio de Janeiro: Editora Nova Fronteira, 2009.

BÍBLIA, A. T. Gênesis. In BÍBLIA. Português. Sagrada Bíblia Católica: Antigo e Novo Testamentos. Tradução de José Simão. São Paulo: Sociedade Bíblica de Aparecida, 2008. p. 18.

ESTÉS, Clarissa Pinkola. Mulheres que correm com os lobos: mitos e histórias do arquétipo da mulher. Trad. Waldea Barcellos. 1 ed. Rio de Janeiro: Rocco, 2018.

HOLLANDA, Heloisa Buarque de (org). Explosão feminista: arte, cultura, política e universidade. 2. Ed. São Paulo: Companhia das Letras, 2018.

MCCANNER, Hannah [et al]. O livro do feminismo. trad. Ana Rodrigues. 1 ed. Rio de Janeiro: Globo Livros, 2019.

COSTA, Gilberto. Estupro bate recorde e maioria das vítimas é de meninas até 13 anos. Jornal Agência Brasil, Brasília, 10 de set. de 2019. Disponível em: http:// agenciabrasil.ebc.com.br/geral/noticia/2019-09/estupro-bate-recorde-e-maioriadas-vitimas-sao-meninas-de-ate-13-anos. Acesso em 11 jan. 2020.

OLIVEIRA. Nielmar de. Pesquisa do IBGE mostra que mulher ganha menos em todas as ocupações. Jornal Agência Brasil, Rio de Janeiro, o8 de mar. de 2019. http:// agenciabrasil.ebc.com.br/geral/noticia/2019-03/pesquisa-do-ibge-mostra-quemulher-ganha-menos-em-todas-ocupacoes. Acesso em 10 jan. 2020.

NOBRE, Carla. Exageros e delicadezas. Belém: Cromos, 2013.

RIBEIRO, Djamila. Quem tem medo do feminismo negro?. 1. ed. São Paulo: Companhia das Letras, 2018.

SANTOS, Maria Helena Amora. Macapá: um rastro de pirilampos. Belém: Cartopack Indústria Gráfica Ltda, 1999.

VIDEIRA, Piedade Lino. Marabaixo, dança afrodescedente: significando a identidade étnica do negro amapaense. Fortaleza: edições UFC, 2009.

WOLF, Naomi. O mito da beleza: como as imagens de beleza são usadas contra as mulheres. Trad. Waldéa Barcellos. 3 ed. Rio de Janeiro: Rosa dos Tempos, 2018.

Recebido em 24/o8/2020.

Aceito em 11/11/2020. 